\title{
SOCJALISTYCZNE I KOMUNISTYCZNE BROSZURY WE FRANCJI W LATACH 1840-1844 ${ }^{1}$
}

\section{FRANÇOIS FOURN}

PRZEŁOŻYŁ: PiOTR KuLIGOWSKI

\begin{abstract}
Abstrakt: Wśród francuskich komunistów i socjalistów w dziewiętnastym wieku broszury były najważniejszym środkiem do szerzenia ich doktryn i organizowania ruchów politycznych. Poza wyjątkami te niedrogie pisma były kierowane przede wszystkim do odbiorców z niższych warstw społecznych, zapraszając ich tym samym do uczestnictwa w polemicznej przestrzeni, którą tworzyły. Broszury były sprzedawane u profesjonalnych księgarzy, ale szerzono je także podczas zgromadzeń, konferencji i strajków. Czytane na głos, mogły one służyć jako podstawa do dyskusji lub zamiennik nudnych przemówień politycznych. Dlatego ich badanie umożliwia wgląd w kontekst dotyczący komunikacji pomiędzy pismem a słowem mówionym i złożonej interakcji między autorami a robotniczymi czytelnikami.
\end{abstract}

Słowa kluczowe: XIX wiek, broszury, Francja, komunizm, propaganda, socjalizm

\footnotetext{
1 Tekst pierwotnie opublikowany w Cahiers d'histoire. Revue d'histoire critique 90-91/2003, 69-83. Dziękujemy redakcji za zgodę na tłumaczenie i przedruk tekstu.
} 
W latach 1840-1844 Louis Blanc i Pierre-Joseph Proudhon rozpoczęli kariery pisarzy socjalistycznych, Étienne Cabet wybrał komunizm², zaś Victor Considérant zaczął przekonywać do fourieryzmu poza wąskimi kręgami, do których był on dotąd ograniczony. Wszyscy uznali konieczność stworzenia nowej przestrzeni debaty i przyczynili się do jej rzeczywistego powstania. Po nieudanych powstaniach z lat 1832 i 1834, a także tym przeprowadzonym przez Stowarzyszenie Pór Roku (Société des Saisons) ${ }^{3}$ w 1839, mogli liczyć już tylko na zjednanie opinii publicznej. Autorzy ci odrzucili więc metodę rewolucyjnego przewrotu, nie wzywali jednak do bierności czy rezygnacji. Dążyli bowiem do upowszechnienia idei, że głębokie reformy ekonomiczne, społeczne i polityczne sa możliwe. Sądzili, że przyszła ludzkość będzie bardziej inteligentna, a społeczeństwo bardziej pokojowe i sprawiedliwsze. Ich postulaty takiej reorganizacji społeczeństwa, by funkcjonowało ono na mniej konfliktowych, a bardziej „braterskich” - jak to wtedy mówiono - zasadach, były niekiedy dyskredytowane i traktowane jako utopie.

Ich marzenia zyskiwały wymiar materialny, który stanowiły broszury, drukowane w dużych ilościach ${ }^{4}$. Oprawione książki były drogie ${ }^{5}$, a czasopisma od wprowadzenia nowego prawa prasowego we wrześniu 1835 roku ${ }^{6}$ mogły być rozpowszechniane tylko wśród abonentów. W przypadku posiadania licznej i zróżnicowanej społecznie grupy odbiorców wydawanie broszur - w porównaniu z innymi dostępnymi środkami - napotykało na najmniej przeszkód. Poprzez publikowanie i rozpowszechnianie broszur socjalistom udało się zmienić i kształtować francuską opinię publiczną. Stało się tak nie tylko dzięki ich sprawnemu dostarczaniu ogromnej liczby druków, ale także za sprawą realnej zdolności stworzenia modelu lektury, który dawał czytelnikom możliwość dostosowywania treści do ich własnych potrzeb.

2 Tylko ten jeden autor opublikował między rokiem 1840 a 1844 aż 56 różnych broszur, nie wliczając ich reedycji lub zbiorów, które pojawiały się corocznie od 1843 r. Oprócz tego wydawał on również własne czasopismo. Łącznie wszystkie broszury autorstwa Cabeta z tego okresu liczą ok. dwóch tysięcy stron.

3 Stowarzyszenie Pór Roku to republikańska organizacja o profilu jakobińskim utworzona w 1837 r. przez Auguste'a Blanqui'ego, Armanda Barbèsa i Martina Bernarda. Autor nawiązuje tu do próby zbrojnej insurekcji podjętej przez Société des Saisons 12 maja 1839 r. W wyniku walk, do których doszło w Paryżu, po stronie rewolucjonistów śmierć poniosło 77 osób, zaś po stronie sił rządowych - 28. Barbès i Blanqui zostali początkowo skazani na śmierć, później jednak karę zmieniono na deportację z Paryża i więzienie (przyp. tłum.).

${ }_{4}^{4}$ Mowa o dużych ilościach według kryteriów epoki, które nie mają nic wspólnego z tymi przywołanymi pod koniec wieku przez Jeana-Yvesa Molliera.

5 Oprawiona książka sprzedawała się dobrze w cenie od 2 do 3 franków. Była to mniej więcej kwota równa dziennemu zarobkowi paryskiego robotnika.

${ }^{6}$ Autor nawiązuje tu do restrykcyjnego prawa prasowego wprowadzonego 9 września 1835 r. W rezultacie wejścia w życie nowych przepisów zamknięto część czasopism lewicowych, których redaktorów oskarżano o obrażanie króla, podżeganie do rewolucji i obrazę funkcjonariuszy publicznych (przyp. tłum.). 


\section{WYDAWANIE: AUTORZY}

\section{Wybór medium}

Broszury socjalistyczne, sprzedawane w niskich cenach, choć skromne z wyglądu, niejednokrotnie zawierały ważkie treści. $\mathrm{Na}$ przykład istotna praca Louisa Blanca L’organisation du Travail była wydana właśnie w formie broszury we wrześniu 1840 roku? Wcześniej, bo w 1839 roku, tekst ukazał się na łamach Revue du Progrès dla ograniczonego grona odbiorców. Tę wielokrotnie wznawianą ${ }^{8}$ broszurę planowano jednak dystrybuować na znacznie szerszą skalę. Pozwoliła ona głoszonym przez Louisa Blanca tezom etatystycznego socjalizmu zyskać prawdziwa popularność. Również skromną z pozoru broszura była praca Proudhona Qu'est-ce que la propriété ? Premier mémoire, opublikowana dwukrotnie, w 1840 i 1841 roku9. Wywołała ona jednak wielki rozgłos.

Wydając dwie broszury w październiku 1840 roku, swą apostolską działalność, mająca na celu szerzenie komunizmu, rozpoczął Étienne Cabet. On sam stał się znany już w latach trzydziestych, ale wówczas głosił jeszcze idee republikańskie. Na początku lat czterdziestych dyskretnie, używając pseudonimu, wydał po raz pierwszy swą Voyage en Icarie gruba książkę, sprzedawaną po sześć franków ${ }^{10}$. Jej dystrybucja była prowadzona ze szczególną ostrożnością i tylko w kręgach osób znajdujących się już pod wpływami komunizmu. Z kolei wydanie Comment je suis communiste ${ }^{11}$ i Credo communiste ${ }^{12}$, czyli małych,

\footnotetext{
7 Broszura liczyła 131 stron w sedecimo [czterokrotnie złożony arkusz papieru, tworzący szesnaście kart i trzydzieści dwie stronice - przyp. tłum.], została wydana w drukarni Pagnerre et Prévot. Na stronie siódmej, we wstępie do swej pracy, Louis Blanc twierdził, że wydanie broszury nastąpiło na wniosek grupy robotników. Tekst tej broszury, podobnie jak większości wspomnianych w niniejszym studium, jest dostępny w Internecie na stronie Gallica (jest to biblioteka cyfrowa BNF). Stosunkowo niedawno ukazało się też drukowane wznowienie broszury z września 1840 r. (Blanc 1979).

8 Pojawiły się liczne reedycje tej pracy, co najmniej pięć do roku 1848 . W późniejszych wydaniach nie była to już broszura, ale oprawiona książka, licząca 284 strony. Piąte wydanie ukazało się w Paryżu, w biurze Société de l'industrie fraternelle.

${ }^{9}$ Były to jedyne publikacje Proudhona aż do pojawienia się, w 1843 r. jego pierwszej prawdziwej książki pt. De la création de l'ordre dans l'Humanité.

10 Właściwy tytuł tej pracy to Voyage et aventures de lord William Carisdall en Icarie, traduit de l'anglais de Francis Adams, par Th. Dufruit maître de langues. Praca ukazała się w drukarni Hippolyte Souverain. Pagnerre, związany z Cabetem przed jego pobytem w Anglii w latach 1834-1839, odmówił druku dzieła. Drugie wydanie pracy ukazało się w drukarni Mallet w 1842 r., tym razem pod tytułem Voyage en Icarie, par M. Cabet, ex-député, exprocureur général, avocat à la cour royale.

11 Po raz pierwszy broszura została wydana w drukarni Bourgogne et Martinet. Jej wznowienie ukazało się w marcu 1841 r., kiedy Cabet rozpoczą wydawanie swego komunistycznego czasopisma Populaire de 1841.

12 Broszura została wydana po raz pierwszy w drukarni Prévot. Podobnie jak poprzednie, także i ta doczekała się wielu wznowień.
} 
liczących szesnaście stron in octavo ${ }^{13}$ broszur, było aktem jego publicznej konwersji na komunizm. 28 października 1841 roku, rok później, znów w formie broszury Cabet opublikował nowy manifest pt. Ma ligne droite ou le vrai chemin du salut pour le Peuple. Lettre à Jules jeune ouvrier ${ }^{14}$. Proponowal tym razem utworzenie, pod swoim kierownictwem, „partii”" komunistycznej, zrzeszającej komunistów rozproszonych w wielu grupach i nurtach ${ }^{15}$. Théodore Dezamy, który potępił ten zamiar, odpowiedział Cabetowi, wydając Code de la Communauté. W przeciwieństwie do swego adwersarza Dezamy opracował teorię komunizmu materialistycznego. Przed dopuszczeniem książki do sprzedaży w cenie czterech franków Dezamy w grudniu 1842 roku opublikował najpierw swój tekst w formie dwudziestu odrębnych broszur, wycenionych po 20 centymów każda. Tak jak komuniści, główni liderzy szkoły sociétaire publikowali broszury, by propagować swoje doktryny, ale także by włączyć fourieryzm w główny nurt ówczesnej myśli socjalistycznej. W 1843 roku na przykład Allyre Bureau wydał w Reims własnym sumptem Manifeste de la Démocratie pacifique w formie broszury. Dopiero później tekst ten ukazał się na łamach pisma redagowanego przez Victora Considéranta. W 1847 roku przeredagował on artykuł, który ukazał się jako broszura pod nowym tytułem Principes du Socialisme, Manifeste de la démocratie au XIXe siècle ${ }^{16}$.

Inne publikowane teksty nie miały ambicji, by kłaść fundamenty pod nowe przekonania. Krótkie komentarze do aktualnych wydarzeń lub interwencje polemiczne pojawiały się w formie mniej kosztownych broszur. Na przykład Cabet w okresie między majem 1841 a lutym 1842 wydał w dwunastu zeszytach ${ }^{17}$ zestaw zróżnicowanych pism pod tytułem Douze lettres d'un communiste à un réformiste sur la communauté. Te broszury zawierały rozmaite pedagogiczne dialogi, wyjaśniające komunizm lub broniące tej idei przed adwersarzami, wycinki prasowe, zapisy procesów sądowych wytaczanych przeciwko komunistów, wreszcie - całe fragmenty utopijnej powieści Voyage en Icarie. Od marca 1841 roku Cabet wydawał także czasopismo Populaire de 1841. Nie chciał on płacić kaucji w wysokości 15 tysięcy franków, wymaganej za wydawanie tygodnika, dlatego też transporty tego pisma były dozwolone tylko raz w miesiącu. Wspomniane Douze lettres miały być umieszczane pomiędzy kolejnymi numerami Populaire’a, aby przełamać ograniczenia wprowadzone przez rzeczone prawo z 1835 roku. Publikacja kolejnych Lettres miała się odbywać niemal co tydzień, choć była czasami zawieszana. Czytelników, którzy skarżyli się na opóźnienia związane z publikacją dziewiątego listu, autor informował, że był zajęty

\footnotetext{
13 Octavo w typografii oznacza arkusz papieru trzykrotnie złożony, który tworzy osiem kart i szesnaście stronic (przyp. tłum.).

${ }^{14}$ Broszura liczyła 64 strony oktawą, było sprzedawana za 30 centymów.

15 Adresse de vingt ouvriers communistes à leurs frères krążył po Paryżu, zbierając setki podpisów. Tekst był wezwaniem do organizowania się w nurcie legalistycznego i pacyfistycznego komunizmu Cabeta.

${ }^{16}$ Broszura wydana w drukarni falansterowskiej liczyła 157 stron złamanych ,osiemnastką”.

${ }^{17}$ Sztywna okładka, obejmująca wszystkie zeszyty, została dołączona w pierwszej dostawie.
} 
rzeczami pilniejszymi lub ważniejszymi, jak choćby publikacją Ma ligne droite lub redagowaniem osobnej broszury o procesie komunisty Françoisa Quénisseta ${ }^{18}$. Mimo wyraźnie niższej rangi przypisywanej zawartości owych Douæe lettres tekst ten, liczący sto sześćdziesiąt sześć stron, był wznawiany trzykrotnie do 1845 roku. Niektóre broszury przedrukowywano jeszcze częściej. Na przykład siódmy list, o kobiecie'19, był do 1845 roku wznowiony dziewięć razy, został on także w 1850 roku przetłumaczony na język niemiecki.

We wszystkich swoich tekstach, bez względu na ich znaczenie, Cabet stosował zawsze jak najprostszy język, by ulotki były przystępne także dla mniej wykształconych czytelników. Publikując drukowane teksty w formie broszur, rozszerzal on zasięg potencjalnego audytorium. Inaczej postępowali fourieryści, wydając teksty niezrozumiałe dla tych, którzy nie byli już wdrożeni w ich doktrynę. Uczestnictwo w doktrynalnych dyskusjach w ramach tej szkoły myśli społecznej zakładało uprzednie poznanie jej koncepcji, a przede wszystkim - skomplikowanego języka. Jednak również fourieryści publikowali broszury przeznaczone dla szerszej publiczności: w tych przypadkach zabronione było używanie żargonu, owej „gwary naukowej”, wedle określenia Victora Considéranta ${ }^{20}$. Chcieli oni dyskutować między soba prace Fouriera, ale także mieli nadzieję na pozyskanie nowych zwolenników i zajęcie ważnego miejsca w debacie o socjalizmie.

\section{Kariery i postacie autorów}

Dla każdego autora i dla każdej szkoły socjalizmu broszury były przedsięwzięciem szczególnym. Mimo ich różnych statusów, mimo pozornego nieładu, ukazywały się one w ramach całościowej strategii wydawniczej wraz z innymi drukowanymi dokumentami, książkami i czasopismami. Towarzyszyły im inne wydarzenia, takie jak konferencje, zebrania, spotkania w domach czy wyjazdy na prowincję. Teksty zyskiwały zatem określone znaczenie nie tylko na tle innych broszur, ale również w kontekście pism przedstawicieli innych nurtów socjalizmu. Publikowanie broszur nie było jedynie środkiem umożliwiającym dyskusję lub

\footnotetext{
18 Komunista ten we wrześniu 1841 r. dokonał ataku na księcia d’Aumale [autor ma tu na myśli nieudany zamach na księcia Henryka Orleańskiego, do którego doszło 13 września 1841 r. - przyp. tłum.].

${ }^{19}$ Broszura pt. La Femme, ses qualités, titres droits. Son malheureux sort dans la présente société. Cause du mal. Remède. Son heureux sort dans la communauté liczyła dwanaście stron in octavo i została wydana po raz pierwszy w lipcu $1841 \mathrm{r}$.

${ }^{20}$ Niemożliwe jest wymienienie tu wszystkich licznych broszur fourierystowskich wydawanych w tym czasie. Warte wspomnienia są wszakże dwie broszury Victora Considéranta, ukazujące możliwość zmiany na poziomie języka. Pierwsza z nich, Description du phalanstère et considérations sociales sur l'architectonique, licząca 111 stron „osiemnastką", wydana w 1840 r., była przeznaczona wyłącznie dla wtajemniczonych. Druga natomiast, Exposition abrégée du système phalanstérien de Fourier, wydana w 1841 r., licząca 114 stron „osiemnastką” i wznawiana trzykrotnie do 1845 r., była pracą mniej „elitarną”.
} 
szerzenie idei, ale także podkreślaniem obecności w debacie publicznej, twarzą w twarz z czytelnikami i z innymi autorami.

Broszury były pisane przez wielkie sławy, ale i nieznane grupy lub pojedynczych autorów wymienionych z nazwiska, a przez to nadających status tekstowi broszury. Działo się jednak również na odwrót: praca nad broszurą mogła tworzyć autora, zwłaszcza w przypadku pisania w kolektywie. Przykładowo 1 lipca 1840 roku miał miejsce bankiet komunistyczny w Belleville. Po raz pierwszy $w$ historii Francji nazwano w ten sposób polityczną demonstrację. Aby uwydatnić historyczny charakter tego wydarzenia, utrwalić pełną emocji chwilę i podkreślić moment ukonstytuowania się „partii” komunistycznej, we wrześniu została opublikowana broszura pod tytułem Premier banquet communiste, le 1er juillet 184021. W istocie tekst ten był transkrypcją toastów wznoszonych przed tysiącem dwustoma uczestnikami tego wydarzenia, był to więc raczej kolaż kilku tekstów. Głosy były liczne, a nawet po części sprzeczne: część przemówień była „unaukowiona”, inne nie, niektórzy mówcy wspominali o władaniu „mieczem równości”, inni tylko o edukacji i moralności. Broszura, gromadząc te wszystkie głosy, była wyrazem „szkoły egalitarnej”, zgromadzonej wokół „chwalebnego sztandaru wspólnoty społecznej”.

Inny tekst, opublikowany w tym samym czasie w innej broszurze, stwierdzał fakt ukonstytuowania się grupy komunistycznej, ale tym razem w Londynie. Opublikowana we wrześniu 1840 roku pod długim tytułem Rapport sur les mesures à prendre et les moyens à employer pour mettre la France dans une voie révolutionnaire, le lendemain d'une insurrection victorieuse effectuée en son sein, lu à la Société démocratique française, à Londres, dans la séance du 18 novembre 1839 , broszura ta nie zawierała wzmianki o autorze, gdyż była napisana zbiorowo przez Towarzystwo Francuskich Wygnańców Republikańskich w Anglii (Société des exilés républicains français en Angleterre) ${ }^{22}$. Była ona zredagowana w formie osiemnastu pytań, z których każde wymagało odrębnej odpowiedzi. Jej autorzy wspólnie zadeklarowali się jako zwolennicy „systemu wspólnotowego”. Początkowo rozpowszechniana we Francji jedynie w tajnych stowarzyszeniach ${ }^{23}$, broszura ta ukazała się ponownie w maju 1841 roku nakładem drukarni królewskiej jako aneks do - sporządzonego przez Giroda de l'Aina - raportu Sądu Koleżeńskiego w związku z atakiem przeprowadzonym przez robotnika Darmèsa na króla

\footnotetext{
${ }^{21}$ Była to broszura licząca 16 stron, sprzedawana po 10 centymów, wydana w drukarni Bourgogne et Martinet. Podpisał się pod nią czteroosobowy komitet redakcyjny: Jean-Jacques Pillot, Théodore Dezamy, Dutilloy i Corneille Homberg,

22 Broszura liczyła 16 stron „oktawa”, wydana została w Londynie w drukarni Thompson. Jej tekst został w 1841 r. określony przez czasopismo Phalange jako „Manifest komunistyczny”. Według informacji z Dictionnaire biographique du mouvement ouvrier français (1997) jednym z głównych autorów tej broszury był lekarz Camille-Louis Berrier-Fontaine, komunista i przyjaciel Cabeta. Oprócz niego autorami byli także Jacques Chilmann, Napoléon Lebon, Jean-Jacques Vignerte, być może Jacques Imbert i Joseph Vilain.

${ }^{23}$ Broszura została skonfiskowana 24 lutego 1841 r. u podwójnego agenta Hodde’a a także, cztery dni później, w budynku malarza Pernina w Belleville.
} 
Ludwika Filipa 15 października 1840 roku²4. Dzięki temu tekst zyskał znaczny rozgłos. Girod de l’Ain, mówiąc o „monstrualnej twórczości” ${ }^{25}$, używał jej jako narzędzia do zastraszania opinii publicznej, której dawał do zrozumienia, że republikanie potajemnie nawracaja się na komunizm.

W przeciwieństwie do tych szczególnych przypadków większość broszur neobabuwistów była publikowana z jasno wskazanymi nazwiskami autorów. Pojawiała się w związku z tym pewna trudność natury teoretycznej. Fakt istnienia podmiotu piszącego, tworzącego oryginalne dzieło, był po części sprzeczny z doktrynami komunizmu. Ze względów praktycznych jednak kierowanie obiegiem myśli dopuszczało możliwość wytwarzania dzieła, którego źródło dawało się zidentyfikować. To sprawiło, że liczni komunistyczni pisarze zabiegali o sławę: Jean-Jacques Pillot $^{26}$, Richard Lahautière ${ }^{27}$, Alphonse Esquiros, Constantin Pecqueur, Jules Gay, Jean i Gabriel Charavay, ksiądz Constant ${ }^{28}$ i jeszcze inni, np. Théodore Dezamy. Ten ostatni próbował stworzyć wokół siebie aurę filozofa czy mędrca ${ }^{29}$. W maju i czerwcu 1840 roku zaczął on wydawać czasopismo L'Égalitaire, journal de l'organisation sociale. Jesienia, publikując Conséquences de l'embastillement et de la paix à tout prix. Dépopulation de la capitale. Trabison du pouvoir ${ }^{30}$, Dezamy zajął stanowisko w kontrowersyjnej kwestii dotyczącej fortyfikacji, które rząd chciał zbudować dookoła Paryża. W listopadzie, wraz z Cabetem, który cieszył się już dużą popularnością, opublikował on broszurę pod tytułem Patriotes français, lisez et rougissez de honte, ou opinion des journaux français et étrangers sur la question d'Orient ${ }^{31}$. Praca została wydana w siedmiuset egzemplarzach. Odtąd Dezamy stał u boku Cabeta i przez rok był jego sekretarzem. Zerwanie między nimi nastąpiło w listopadzie lub grudniu 1841 roku. Wtedy to Dezamy opublikował długi tekst M. Lamennais

\footnotetext{
${ }^{24}$ Broszura liczyła 88 stron.

${ }^{25}$ Wspomina o tym na stronie 68 raportu.

${ }^{26}$ Był to autor, którego część broszur zyskała spory rozgłos. Należy tu wymienić teksty takie jak Ni châteaux ni chaumières ou état de la question sociale en 1840 (wydana w maju 1840 r., licząca 60 stron, złamana ,trzydziestka dwójka", sprzedawana za 30 centymów). W sierpniu 1840 r. wydał on Histoire des Égaux ou moyen d'établir l'égalité absolue parmi les hommes (60 stron, złamana „trzydziestką dwójką), zaś w październiku 1841 r. La Communauté n'est plus une utopie! Conséquences du progrès des Communistes (32 strony „oktawą”, sprzedawana po 30 centymów).

${ }^{27} \mathrm{~W}$ maju 1841 r. zaczął on wydawać pismo Fraternité, które było konkurencyjne dla magazynu Populaire Cabeta. Wydawał on także broszury, na przykład Les déjeuners de Pierre. Dialogues w drukarni Prévot, cztery zeszyty po 12 stron, sprzedawana po 10 centymów każda. Poszczególne zeszyty ukazywały się od kwietnia do lipca $1841 \mathrm{r}$.

${ }^{28}$ W 1841 r. w drukarni A. Gallois opublikował on trzy broszury: La Bible de la Liberté (111 stron, złamana „dwunastką”), L'Assomption de la Femme (252 strony „osiemnastką") i Doctrines religieuses et sociales (85 stron „osiemnastka”). Więcej informacji na temat tego autora znaleźć można w książce Paula Bénichou’a (Bénichou 1977, 435-446). Bénichou zajmował się także Alphonsem Esquiros i Florą Tristan.

${ }^{29}$ Kariere publicysty rozpoczął on w grudniu 1838 r., odpowiadając na pytanie akademii nauk moralnych i politycznych. Jego odpowiedź została opublikowana w 1839 r. w broszurze liczacej 68 stron „oktawa”.

30 Była to niewielka broszura licząca 16 stron „oktawa”, sprzedawana po 15 centymów w drukarni Rouannet.

${ }^{31}$ Broszura ukazała się w drukarni Rouannet et Prévot.
} 
réfuté par lui-même, ou examen critique du livre intitulé Du passé et de l'avenir du Peuple, puis Dialogue sur la réforme électorale entre un Communiste, un Réformiste, un Doctrinaire, un Légitimiste 32 . Oddał się on tu poszukiwaniom teoretycznym, stawiając sobie za cel obronę pozycji komunistycznych przed atakami reformistów. Ponownie, już bez Cabeta, zajął stanowisko w dyskusji politycznej. W lutym 1842 roku Dezamy zaczął publikować swą najważniejszą pracę, Code de la Communautê3. Wraz z ukazaniem się tego tekstu, zawierającego obszerną krytykę Voyage en Icarie, Dezamy został na jakiś czas największym adwersarzem Cabeta. Polemika między nimi toczyła się w serii kolejnych publikacji ${ }^{34}$. Wymieniano obelgi, przede wszystkim jednak ujawniły się wówczas dzielące ich rzeczywiste różnice doktrynalne. Dotyczyły one przyszłych relacji między burżuazja a proletariatem. Dla Cabeta emancypacja proletariatu bez udziału burżuazji była niemożliwa. Według Dezamy’ego natomiast proletariat nie mógł od burżuazji oczekiwać niczego. To zderzenie najwybitniejszych autorów komunistycznych pozwoliło Dezamy’emu ogłosić się głównym inspiratorem komunizmu, oferującym wizję alternatywną wobec tej z Voyage en Icarie. W 1842 i 1843 roku opublikował on almanachy z „różnymi pismami komunistycznymi”"35. Od czerwca do października 1844 Dezamy przebywał w więzieniu za wydanie Almanach de l'organisation sociale.

\section{Trudności}

\section{Zaangażowanie}

Fakt, że ktoś stawał się rozpoznawalną twarzą socjalizmu, nie był rezultatem samego oddziaływania tekstów. Pisanie było tylko częścią walki, umożliwiającą istnienie w przestrzeni publicznej. Praca nad broszurami socjalistycznymi pociagała za sobą zaangażowanie, które wykraczało poza samą produkcję tekstów: autorzy ryzykowali, że zostanie przeciw nim wszczęte postępowanie karne. Ich materiały propagandowe były adresowane przede wszystkim do robotników i ubogiej części społeczeństwa. Pisarze socjalistyczni chętnie

\footnotetext{
32 Była to broszura licząca 96 stron „osiemnastką”.

33 Publikacja tej broszury w osobnych częściach miała miejsce w grudniu 1842 r. Składała się ona z 20 części liczących łącznie 296 stron „oktawą”, każda część była sprzedawana po 20 centymów. Księgarze Prévot i Rouannet pomagali Dezamy’emu w edycji, zabezpieczając się przedpłatami, a zwłaszcza rachunkiem autora. Po ukończeniu, jak zwykle, praca została wznowiona i była sprzedawana po 4 franki. W 1967 r. wydrukowano na nowo 500 egzemplarzy dzieła.

34 Polemika toczyła się w następujących broszurach: Cabet, Propagande communiste ou question à discuter et à soutenir ou à écarter (10 stron „oktawą), Dezamy, Calomnies et politiques de M. Cabet, réfutation par des faits et par sa biographie (48 stron „osiemnastką”, sprzedawana po 50 centymów), Cabet, Toute la vérité au Peuple, ou réfutation d'un pamphlet calomniateur (114 stron „oktawa”, sprzedawana - podobnie jak broszura, którą Cabet atakował - po 50 centymów).

35 Konkretnie opublikował on Almanach de la Communauté pour 1843 we współautorstwie z Jules'em Gay, Jeanem-Josephem May i Jeanem-Jacques'em Navelem.
} 
przyjmowali ofiary pieniężne, pomocne by wydawać teksty i udostępniać je klasom ludowym po bardzo niskiej cenie. Opowieść o trwających trudnościach, czasem o cierpieniach i prześladowaniach, była dobrym chwytem reklamowym. Robiono wszystko, by przekonać innych o bezgranicznym oddaniu dla sprawy.

Flora Tristan bardzo zaangażowała się, aby jej praca pt. Union ouvrière ${ }^{36}$ mogła zaistnieć. Ten dość krótki tekst ${ }^{37}$ został napisany w ciągu sześciu tygodni, między grudniem 1842 a końcem stycznia 1843 roku. Republikański wydawca Pagnerre, z którym autorka się skontaktowała, odmówił wydania pracy z uwagi na jej przekaz ${ }^{38}$. Wysłała ona więc kopię tekstu do Victora Considéranta i obszerne fragmenty ukazały się na łamach pisma Phalange 29 i 31 marca. Tristan, jakkolwiek mile zaskoczona, postanowiła na tym nie poprzestawać. 2 kwietnia, po kilkudniowym przygnębieniu, postanowiła sama zorganizować subskrypcję na wydanie swej książki. Wyruszyła na piechotę do Paryża. Do 17 maja udało jej się zebrać sumę 1500 franków, co było kwotą w zupełności wystarczającą na sfinansowanie pierwszego nakładu, który wynosił cztery tysiące egzemplarzy. Księgarze Prévot i Rouannet zgodzili się jej pomóc. Koszt wydruku i oprawy Union ouvrière wyniósł ostatecznie 932 franki. Część egzemplarzy otrzymali subskrybenci, pozostałe zaś rozdawano za darmo lub sprzedawano za pięćdziesiąt centymów. Do stycznia 1844 roku zostało wykupionych 1500 egzemplarzy. Tristan zdecydowała się więc na drugie wydanie, tym razem w nakładzie liczącym dziesięć tysięcy egzemplarzy. Ponieważ nie udało się jej odzyskać form drukarskich wykorzystanych w pierwszym wydaniu, musiała zrobić nowy skład ${ }^{39}$. Koszt drugiego wydania wyniósł 2200 franków. Książka ukazała się 16 marca 1844 roku. Na to właśnie czekała Tristan, by rozpoczać podróż po Francji. W maju 1844 roku była w Lyonie, gdzie grupa robotników obiecała jej przekazać 1000 franków na trzecie wydanie Union ouvrière. Tristan napisała krótki wstęp, który dodano do tych z dwóch pierwszych edycji. Sama zorganizowała zakup papieru i zaplanowała $z$ drukarzem prace nad składem ${ }^{40}$. Trzecie wydanie, tak jak poprzednie, miało nakład 2000 egzemplarzy.

Walka, którą Tristan musiała stoczyć, by wydać swą książkę, nie była niczym wyjątkowym. Finansowanie publikacji stanowiło problem, z którym zmagali się prawie wszyscy autorzy broszur socjalistycznych. Na przykład Proudhon w 1840 roku mógł wydać własnym sumptem tylko 500 egzemplarzy swojej pracy Qu'est-ce que la propriété ?. W 1841 roku udało mu się nawiązać współpracę z Prévotem, paryskim księgarzem. Jej celem było drugie

\footnotetext{
36 Pojawiło się już sporo opracowań o tej niewielkiej broszurze, na przykład autorstwa Stéphane’a Michauda lub liczący 95 stron wstęp napisany przez Daniela Armogathe’a i Jacques'a Grandjonca, opublikowany w nowym wydaniu dzieła Flory Tristan w 1986 r. w edycji Des Femmes.

${ }^{37} \mathrm{~W}$ zależności od wydania tekst liczył między 144 a 180 stron.

38 Jego list, z datą 31 marca, jest cytowany w całości we wstępach do trzech pierwszych wydań broszury.

${ }^{39} \mathrm{~W}$ drukarni Worms w Montmartre.

${ }^{40}$ Nie udało jej się w Lyonie powtórzyć tego, co zrealizowała w Paryżu.
} 
wydanie broszury, tym razem w nakładzie 3000 egzemplarzy. Umowa między autorem i księgarzem była następująca: Proudhon miał dostarczyć arkusze wydrukowane własnym sumptem w Besançon, natomiast Prévot, który miał je zszyć i oprawić, zobowiązywał się z góry do zakupu 1400 egzemplarzy i otrzymywał wyłączność na sprzedaż pozostałych (Haubtmann 1982, 282-283).

Cabet w swych pismach nieustannie przywoływał różne trudności finansowe związane $\mathrm{z}$ propagowaniem doktryny komunizmu ikaryjskiego, prosząc $\mathrm{w}$ ten sposób o pomoc. Najwyraźniej jedynie fourieryści nie mieli problemów związanych z brakiem pieniędzy: ich czytelnicy byli zamożniejsi.

\section{Recepcja: czytelnicy}

Badania nad recepcja tekstów moga budzić zastrzeżenia o tyle, że dostępna pozostaje tu jedynie produkcja zwrotna, która nie mówi zbyt wiele o społecznym odbiorze treści. Próba przeprowadzenia tego typu badań jest jednak konieczna: na historyczność broszur socjalistycznych z początków lat czterdziestych składa się nie tylko ich pisanie i wydawanie, ale w nie mniejszym stopniu także to, jak zawarte w nich treści interpretowali i stosowali ci, którzy je czytali (Chartier 1996, 134-154).

Dla części czytelników tworzenie archiwów było czymś oczywistym. Grupa szczególnie uważnych odbiorców, troszczących się o to, by donieść o swojej lekturze, byli dziennikarze wszystkich opcji politycznych. Teksty publikowane w formie broszur przez autorów socjalistycznych prowadziły między sobą dialog, a także reagowały na artykuły zamieszczane w czasopismach redagowanych przez przeciwników. W ramach tej wzajemnej lektury rozwijała się krytyka, dochodziło do konfrontacji, rosło pragnienie tworzenia nowych tekstów.

Inną kategorią uważnych czytelników, również dbałych o sporządzenie raportu zlektury, byli przedstawiciele władzy: policjanci i sędziowie zobowiązani do nadzoru i w szczególnych przypadkach do wstrzymania publikacji broszur uznanych za wywrotowe. Ich działania wymagały szczególnej ostrożności, bo zdarzało się, że sięgnięcie po środki prawne wywoływało niespodziewane skutki. Na przykład 25 sierpnia 1840 roku prokurator generalny Paryża, odnosząc się do właśnie przeczytanej przez siebie broszury Jeana-Jacques’a Pillota pt. l'Histoire des Égaux, pisal do Garde des Sceaux: „Wytoczenie procesu autorowi oznaczałoby nadanie mu zbyt dużego znaczenia, w chwili gdy zasługuje on tylko na publiczne zlekceważenie" ${ }^{41}$. Z kolei inni byli ścigani: ksiądz Constant na przykład w 1841 roku został

\footnotetext{
41 Archives nationales, BB18 1387, dos. 997.
} 
skazany na osiem miesięcy więzienia za swoje trzy inspirowane komunizmem prace. Tego samego roku sam Jean-Jacques Pillot został skazany pośrednio za utworzenie tajnego stowarzyszenia. Ogólnie rzecz biorąc, w innych przypadkach policja i wymiar sprawiedliwości nie zapobiegały publikowaniu i rozpowszechnianiu pism przez autorów socjalistycznych. Władze monarchii lipcowej przed rokiem 1846 i 1847 nie dostrzegły faktu, że dzieła socjalistyczne destabilizują ich reżim ${ }^{42}$. Zaczęły one odczuwać niepokój, kiedy spostrzegły, że socjalistycznym publicystom udało się dotrzeć do robotników. Wtedy było jednak już za późno.

Przybliżenie tutaj recepcji pism socjalistycznych we wszystkich środowiskach francuskich robotników jest niemożliwe, można jednak pokusić się o omówienie jednego, szczególnego miasta. Relatywnie liczne źródła, w każdym razie liczniejsze niż w przypadku innych miejsc, zachowały się w odniesieniu do robotników Lyonu. Są to przede wszystkim raporty prokuratora generalnego Piou au Garde des Sceaux Martin du Nord ${ }^{43}$, relacje z podróży pisarzy socjalistycznych, a także korespondencja autorów paryskich z ich lyońskimi czytelnikami. Na podstawie tych źródeł możliwe jest ustalenie kilku faktów związanych $\mathrm{z}$ recepcją pism socjalistycznych w Lyonie w latach 1842-1844.

\section{Rozpowszechnianie broszur socjalistycznych w Lyonie, 1842-1844}

Do rozprowadzania broszur konieczny był zorganizowany system sprzedaży, nie decydował on jednak o wszystkim. Czytelnicy musieli bowiem okazać gotowość na przyjęcie przekazu, który był do nich adresowany. Sytuacja nie wyglądała tak, że z jednej strony byli aktywni nadawcy i popularyzatorzy, a z drugiej odbiorcy zajmujący pozycję bierną i wyczekująca. Recepcja bojowych tekstów nie była rezultatem zwykłej działalności handlowej.

Étienne Cabet na przykład nie rozprowadzał swych pism za pośrednictwem fachowych księgarni. Aż do 1842 roku jego broszury otrzymywała droga pocztowa grupa lyońskich robotników, która zajmowała się ich dystrybucja, płacąc za nie później. Utworzyli oni rodzaj komitetu korespondencyjnego. W sierpniu 1842 roku robotnicy ci otrzymali pakiet pięćdziesięciu egzemplarzy broszury Toute la vérité au peuple. Przez następny miesiąc milczeli. We wrześniu napisali do Cabeta, że potępiaja oni wydanie tekstu napisanego przeciwko Dezamy'emu i że naradziwszy się, odmawiają jego dystrybucji. Trzydzieści siedem egzemplarzy broszury zostało odesłane do Paryża. Czwartego października Cabet wydał

42 Zob. w szczególności często cytowany raport prefekta policji Gabriela Delesserta, datowany na 19 stycznia 1847 r., o „Publikacjach anarchistycznych z 1846 r.” (Garnier-Pagès 1861, 156).

${ }^{43}$ Dobrze zachowane w zespole BB18 Archives nationales, w szczególności kartony BB18 1414 (dos. 7012), BB18 1415 (dos. 7135), BB18 1419, BB18 1420 (dossiers 8195 i 8133), BB18 1423 (dossiers 8701a9 et 9801), BB18 1428 (dos. 9580), BB18 1438 (dos. 1219). 
nową broszurę44, w której oskarżał swych zbuntowanych korespondentów o uleganie wpływowi materialistycznego i rewolucyjnego komunizmu Lahautière’a i Dezamy'ego. Inni, w szczególności Chapuis, szef warsztatu Croix-Rousse, pozostali mu wierni. Chapuis został jego głównym źródłem kontaktów w Lyonie i to on otrzymywał odtąd z Paryża paczki $\mathrm{z}$ materiałami propagandowymi, przeznaczonymi do dystrybucji w całym regionie lyońskim. U jego boku działała grupa innych oddanych robotników, do której zaliczyć można przede wszystkim krawców Gluntza i Faucona. Do Chapuisa przychodzili wszyscy zainteresowani komunistyczną propagandą Cabeta, a stanowili oni w Lyonie liczna grupę. Korespondent ustalił listę swych współpracowników.

We wrześniu 1843 roku, aby zwiększyć liczbę nowych adeptów, Cabet sam udał się na miejsce w towarzystwie paryskiego krawca, Firmina Favarda. Obaj zostali przedstawieni w licznych kołach robotniczych. Poświadczone źródłowo są także inne tego rodzaju wizyty, których celem było promowanie niedawno wydanych broszur, przykładowo wizyta Flory Tristan (Tristan 1980a, 112-186; Tristan 1980b, 5-36) ${ }^{45}$, długi pobyt Proudhona, podróż Julesa Leroux (brata Pierre'a Leroux) ${ }^{46}$, Louisa Blanca i wielu innych.

Po przyjeździe do Lyonu Cabet wybrał na głównego depozytariusza książek, broszur i czasopism krawca Faucona. W 1844 roku Faucon zaangażował się w działalność nielegalnego stowarzyszenia. Policja odkryła, że w Lyonie powstały „biblioteki”, gdzie spotykali się w grupie liczącej ok. dwudziestu osób ${ }^{47}$ robotnicy, którzy dzięki składkom wspólnie kupowali książki i broszury komunistyczne ${ }^{48}$. Spotykali się oni, aby je wspólnie czytać, omawiać i rozprowadzać w warsztatach. Członkowie bibliotek gromadzili się przy okazji bankietów urządzanych z okazji rocznic wydarzeń z historii rewolucji. 19 września 1844 roku odbył się proces dwunastu działaczy. Faucon został uniewinniony; wszystko odbyło się bez jego wiedzy. Cabet zaś nie był niczego świadomy, organizacja bowiem powstała bez niego. Żadna z osób, które wykazały się tak dużym zapałem w szerzeniu jego idei, nie skonsultowała z nim tego pomysłu. Cabet wszystko to potępił. W grudniu 1844 roku opublikował skierowaną częściowo przeciw środowisku Faucota broszurę pod wymownym tytułem Les masques arrachés ${ }^{49}$.

44 Cabet, Utile et franche explication avec les communistes lyonnais sur des questions pratiques, 30 stron "oktawa".

45 Zob. także Archives nationales, karton BB18 1420 (dos. 8133).

46 Jules Leroux, co było rzadkie wśród socjalistów, w istocie nie wydawał broszur. Co najwyżej sprzedawane były przedruki jego artykułów z pisma Revue indépendante. Między rokiem 1840 a 1843 pojawiło się pięć takich publikacji.

47 Dwadzieścia osób to limit legalnego zgromadzenia ustalony w $1834 \mathrm{r}$.

48 Zob. w szczególności raport prokuratora królewskiego, datowany na 21 września 1844 r. Archives nationales, BB18 1423 (dos. 8701a9). Pisał o tym także Cabet w Les Masques arrachés (s. 41-42).

49 Broszura liczyła 144 strony „oktawą”, została opublikowana 14 grudnia 1844 r. „w imieniu i na koszt zgromadzenia akcjonariuszy pisma Populaire”. 
Flora Tristan w dzienniku, który prowadziła podczas swojej podróży po Francji, a także w swej korespondencji (Tristan 1995) odnotowywała, na co narażała się, rozprowadzając teksty propagandowe. Podobnie jak Cabet podróżowała ona po to, by na żywo przekazywać wiedzę o organizacji, którą przedstawiła w swej broszurze Union ouvrière. Tristan nie dbała o to, czy jej praca znajdzie się w fachowych księgarniach. Przeciwnie: rozpowszechniała ja przede wszystkim na spotkaniach robotników, którzy po zakończeniu dyskusji decydowali się na zakup. Podobnie jak Cabet Tristan próbowała pozyskać zwolenników gotowych kontynuować dzieło popularyzacji już bez niej samej. Miała ona okazję spotkać i zaangażować w działalność oddaną aktywistkę, Eléonore Blanc.

\section{Praktyki czytelnicze}

W początkach lat czterdziestych poświadczoną źródłowo praktyką w środowiskach robotników w Lyonie było czytanie na głos czasopism i broszur przed słuchająca publicznościa. Choć źródła wskazują zwłaszcza na tę praktykę czytelniczą, nie ma jednak pewności, czy przeważała ona nad innymi. W każdym razie nie była jedyna. Podczas lektury dokumentów ukazujących te zgromadzenia słuchaczy można odnieść wrażenie, że większość obecnych wiedziała już o tym, czego teksty dotyczą. Tristan w swym dzienniku, pisząc o „najbardziej uprzywilejowanych spośród lyońskich robotników”, odnotowywała, że niektórzy tkacze czytali w czasie pracy (Tristan 1980a, 132). Nie należy lekceważyć zatem ani mocy przerobowych, jakie posiadali w tamtym okresie lyońscy robotnicy, jeśli chodzi o czytanie, ani ich poziomu świadomości politycznej. Ich lektury nie sprowadzały się do szkolenia z socjalizmu. Flora Tristan mogła złościć się na komunistki i komunistów, których poznała i których miała za ludzi upartych i dogmatycznych, w rzeczywistości jednak czytali oni różne rzeczy. Większość autorów zapraszała zróżnicowane grona czytelników, aby dowiedzieć się o innych systemach socjalistycznych. Robotnicy postępowali podobnie. Do czytanych tekstów nie podchodzili na kolanach. Lektura była dla nich przygotowaniem do sporu, dyskusji i do późniejszej debaty politycznej.

\section{Debaty}

Połączone z dystrybucja i czytaniem broszur debaty budziły w środowisku lyońskich robotników większe emocje niż sama lektura, która je poprzedzała. Joseph Benoit, długi czas po tym, jak obserwował narodziny ruchu socjalistycznego w Lyonie, utrwalił wspomnienie tamtych realiów. Być może nieco idealizował, pisząc: 
Spotkania na świeżym powietrzu, latem w lesie lub na łąkach w pobliżu Lyonu, zimą zaś w zakładach, wieńczyły dzieło rozpoczęte przez książki, dodając do lektur komentarze konieczne dla ich zrozumienia. Wyobraźmy sobie dwadzieścia lub trzydzieści osób w różnym wieku i różnej płci, zebranych w warsztacie tkackim i porozsadzanych we wszystkich wolnych miejscach między krosnami, oświetlonych przez jedną lub dwie pracownicze lampy, rzucające wątłe światło. Uzyskamy obraz spotkań, w czasie których pogrążone w bólu dusze szukały chciwie pocieszenia w obietnicy, jaką dawała dyskusja, lub w wiedzy na temat zjawisk społecznych i źródeł zła. Czasami zgromadzenia te miały miejsce się w warsztacie introligatorskim, dużej izbie, mogącej pomieścić większą liczbę słuchaczy. Niejednokrotnie w czasie tych spotkań widziałem, jak ludowi mówcy, robotnicy, prostym i sugestywnym wystapieniem oczarowywali publiczność. Obraz teraźniejszych krzywd i wyobrażenie radosnej przyszłości w przebudowanym społeczeństwie nieraz wyciskały łzy żalu i cierpienia, podczas gdy upojna wizja szczęśliwości wywoływała łzy zachwytu i nadziei (Benoit 1968, 74-75).

Z innych źródeł traktujących o spotkaniach, podczas których robotnicy dyskutowali między sobą o tym, co przeczytali w otrzymywanych broszurach i socjalistycznej prasie, można wymienić w szczególności archiwa sądowe. Policja bowiem nieraz przechwytywała teksty przemówień przygotowane przez mówców ${ }^{50}$.

Ogólnie rzecz biorac, akulturacja polityczna dokonująca się poprzez broszury zostawiała miejsce na kontestację i intelektualną wolność czytelników. Ta zdolność do wyrażania odmiennego stanowiska i umiejętność krytycznego słuchania rozczarowywały i wycieńczały Florę Tristan. Niechęć do ulegania, brak skłonności do podążania za stadem niepokoiły Cabeta, świadomego, że skutki wywoływane przez jego teksty wymykają się jego kontroli i mogą mu być nie na rękę.

\section{Działania podejmowane po lekturze i dyskusji wokół broszur}

Lyońscy robotnicy mogli więc dostarczane im przez paryskich socjalistów broszury wykorzystywać do lokalnej działalności, która wykraczała poza praktykę językowa.

Wiosną 1844 trwał strajk górników z Rive-de-Gier, którzy obawiali się połączenia siedemnastu firm, dzielących się do tej pory eksploatacja zagłębia węglowego, w jedną wspólną kompanię. Deklarowanym celem tego przedsięwzięcia była racjonalizacja produkcji i obniżenie kosztów wydobycia, faktycznie chodziło o obniżenie płac. Pierwszego maja 1844 roku dwa tysiące górników zaprzestało pracy i zorganizowało demonstracje przy wejściach do

${ }^{50}$ Archives nationales, BB18 1414 (dos. 7012). Tekst skonfiskowany 10 sierpnia 1843 r. 
kopalń. Nędza w zagłębiu węglowym stała się ogromna, ale strajkujący nie ustępowali. Żony górników zmuszone były żebrać o jedzenie w pobliskich wsiach. Około 15 maja trzeba było przerwać strajk, jednak nie uspokoiło to prokuratora generalnego Lyonu. Od 25 kwietnia w mieście trwała zbiórka pieniędzy na górników. Pozyskane z niej kwoty wysyłano do Givors, stamtad trzeba było dostarczyć je do Rive-de-Gier. Gdy u właściciela lokalnej kawiarni Villarda ${ }^{51}$ nakazano rewizję, część pieniędzy przeznaczonych na wsparcie strajku została skonfiskowana, podobnie jak komunistyczne broszury, przede wszystkim prace Cabeta. Działacze robotniczy z Lyonu martwili się nie tylko o dotarcie z pomocą materialną do rodzin wygłodzonych górników. Przekazywaniu datków towarzyszyła dystrybucja broszur i czasopism. W kolejnych latach, jeszcze przed 1846 rokiem Rive-de-Gier, które do tej pory nie pojawiało się w dysputach socjalistów, znalazło się pośród dwudziestu francuskich miast składających u Cabeta największe zamówienia na jego materiały propagandowe. Odtąd miał on na miejscu energicznego korespondenta, niejakiego Brissaca, który w 1845 zają się intensywnie bezpośrednią dystrybucją jego pism, roznosząc je „od drzwi do drzwi”.

\section{Wnioski}

Oprócz pytania o to, co socjalistyczne broszury oznaczały dla ich autorów i czytelników w początkach lat czterdziestych dziewiętnastego wieku, otwartą pozostaje kwestia użytku z nich dla dzisiejszego pisarstwa historycznego. Jako materiały źródłowe broszury oferuja pewne udogodnienia, ale związane są też z nimi pewne trudności. Na okładce prawie zawsze wymienione zostaja miejsce i data wydania, autor lub grupa autorów, wydawca, cena, główne punkty sprzedaży i informacja, czy broszura stanowi część jakiegoś cyklu ${ }^{52}$. Są to liczne wskazówki, dzięki którym można precyzyjnie określić okoliczności powstania danej broszury. Jednak wielu historyków nad ten typ źródeł przedkłada inne, które uchodzą za bardziej transparentne: rękopiśmienna korespondencja, dokumenty przechowywane w prywatnych lub publicznych archiwach, teksty literackie, prace „naukowe”, a nawet artykuly prasowe. Produkowane najczęściej w celach propagandowych broszury budzą podejrzenia, że moga rozmijać się z rzeczywistością.

Broszury jednak - bardziej, niż mogłoby się wydawać na pierwszy rzut oka - stanowia niezwykle bogaty materiał dla historyków. Mogą one pomóc w dostrzeżeniu faktów niekiedy trudnych do uchwycenia. Dokumenty takie jak korespondencja, artykuły z czasopism, raporty policyjne czy archiwa sądowe nie są w stanie oddać wszystkich realiów politycznych i społecznych. Broszury publikowane w latach czterdziestych to dokumenty, w których tekst

\footnotetext{
51 Le Populaire de 1841, 5 czerwca 1844.

52 Często na tylnej okładce drukowane były reklamy.
} 
był komponowany tak, by odpowiadał językowi mówionemu. Broszury wtórowały rozmowie, służyły do rozwijania rozpoczętych na spotkaniach dyskusji, do ponownego wszczynania sporów, ich ożywiania. Częściej niż jakikolwiek inny rodzaj druków były one używane przez francuskich myślicieli i działaczy socjalistycznych na pierwszym froncie politycznej walki. Przeznaczone do szybkiego czytania, powiązane z bieżąca sytuacją, broszury przechowuja z natury krótkotrwały kontekst komunikacji. Do dzieł ambitnych, pisanych z myślą o potomności nie przedostają się ostre słowa, bo autor zazwyczaj „w porę” ich pożałuje. Nieostrożność mogła zagrozić istnieniu czasopisma, podczas gdy broszura nie podlegała tym samym zakazom. Były to najtańsze drukowane teksty w okresie poprzedzającym rewolucję lutową roku 1848. Z tych powodów było to medium, które dawało szansę na największą wolność pisania, czytania i mówienia. 


\section{Wykaz literatury}

1997. Dictionnaire biographique du mouvement ouvrier français. Sous la direction de Jean Maitron. Paris: L'Atelier.

Bénichou, Paul. 1977. Le Temps des prophètes, doctrines de l'âge romantique. Paris: Gallimard, NRF.

Benoit, Joseph. 1968. Confessions d'un prolétaire (Lyon 1871). Présentées par Maurice Moissonnier. Paris: Éditions sociales.

Blanc, Louis. 1979. Les Révolutions du XIXe siècle. Vol. III. La propagande socialiste de 1835 à 1848. Paris: EDHIS.

Chartier, Roger. 1996. Culture écrite et société, L’ordre des livres. Paris: Albin Michel.

Garnier-Pagès, Louis-Antoine. 1861. Histoire de la Révolution de 1848. Vol. 1. Paris: Pagnerre.

Haubtmann, Pierre. 1982. Pierre-Joseph Proudhon, Sa vie et sa pensée (1809-1849). Paris: Beauchesne.

Tristan, Flora. 1980a. Le Tour de France. Journal 1843-1844. Vol. 1. Paris: François Maspéro. Tristan, Flora. 1980b. Le Tour de France. Journal 1843-1844. Vol. 2. Paris: François Maspéro. Tristan, Flora. 1995. La paria et son rêve, Correspondance. Etablie par Stéphane Michaud. Fontenay-aux-Roses: ENS Éditions. 
François Fourn - francuski historyk, autor książki Étienne Cabet ou Le temps de l'utopie (2014).

\section{DANE ADRESOWE:}

Lycée Victor Duruy

33 boulevard des Invalides

75007 Paris

EMAIL: fournfrancois@gmail.com

CYTOWANIE: Fourn, François. 2017. „Socjalistyczne i komunistyczne we Francji w latach 1840-1844", Praktyka Teoretyczna 1(23): 195-212.

DOI: $10.14746 /$ prt.2017.1.7

\section{AUTHOR: François Fourn}

TITLE: Socialist and Communist Brochures in France between 1840 and 1844

ABSTRACT: For the French communists and socialists of the 19th century, brochures were the most important means used to spread their doctrines and to organize political movements. With some exceptions, these cheap works were targeted to an audience from lower social strata, thereby inviting them to take part in the polemical space which they created. Brochures were available from specialist booksellers, but they were also distributed during meetings, conferences, and strikes. While read aloud, they could serve as a launch pad for political discussions or as a substitute for political speeches. For these reasons, the examination of brochures offers insights into the context of communication between writers and readers and sheds light on the interaction between the written and spoken word.

KEYWORDS: brochures, communism, France, propaganda, socialism, the 19th century 